\title{
Social Capital: Foundations and Some Social Policies in the EU
}

\author{
Alfredo Rodríguez-Sedano ${ }^{1}$, Ana Costa-Paris ${ }^{1}$, Juan Carlos Aguilera ${ }^{2}$ \\ ${ }^{1}$ Department of Education, University of Navarra, Pamplona, Spain \\ ${ }^{2}$ Faculty of Education, University of the Andes, Santiago, Chile \\ Email: arsedano@unav.es, acosta@unav.es, jcaguilera@uandes.cl
}

Received June $5^{\text {th }}$, 2012; revised July $11^{\text {th }}$, 2012; accepted July $25^{\text {th }}$, 2012

\begin{abstract}
With this paper we want to show which three pillars are fundamental that lie within the social capital: trust, cooperation and the principle of general reciprocity. Some significant data about Abortion in the EU-27 and in the EU-15 awaken us to realize the existence of social phenomena's that can undermine the social capital foundations and resent the people as well as the society, to the extent in which the social policies affect; trust, cooperation and the general principal of reciprocity. Finally, we suggest the promotion of public policies, the increase of public resources, as well as to launch campaigns to re-evaluate and rethink the personal and social importance of these foundations. We also see the necessity of avoiding the various manifestations that lead us to undermine these foundations.
\end{abstract}

Keywords: Social Capital; Trust; Cooperation; Reciprocity

\section{Introduction}

From a social point of view the reality of abortion is highly significant in the social settings and development of each country. From the perspective provided by the Social Capital, abortion does not precisely contribute to the societies cohesion intended.

A fairly general definition of the term regards social capital as a quality of social groups, generally whole societies, which is generated when individuals associate together with particular aims in mind, including cultural as well as socio-structural aspects such as rules of behavior, security, proactive attitudes, social integration or trust (Borgatti, Jones, \& Everett, 1998). This definition emphasizes the group-collective dimension of social capital, and has been used in recent years as a key concept in research into processes of economic and social or community development (Grootaert \& van Bastelaer, 2002; Knack \& Keefer, 1997; Torsvik, 1999, 2000; Woolcock, 1998; Woolcock \& Narayan, 2000), and as a mechanism in the explanation of collective action and behaviors of association and social participation (Coleman, 1988; Putnam, 1995, 1996, 2000). In this sense, social capital has been shown to be an important factor in the analysis of the economic development of poor societies, as well as in the course of political transition processes or the restoration of social cohesion after various kinds of conflict or social problem.

The premise underlying social capital is that interaction enables people to create communities, to form commitments and weave social networks. This sense of belonging and concrete experience of social networks can benefit both the people themselves and the activities that are carried out.

The role of social networks in protecting people in times of need has well-established microfoundations in economic theories of mutual insurance (Thomas \& Worral, 2002), altruism, social norms (Hechter, 1987), and reciprocity in games of repeated play (Fudenberg \& Maskin, 1986).

These theories all suggest that social capital is greater when individuals are embedded within a dense network of social ties so that cooperation can be monitored and rewarded by others, or when there is affection amongst individuals that promotes altruism and expectations of future reciprocity. These theories also stress the importance of long-term relationships and expected future encounters. Long-term relationships provide incentives for cooperative behavior and the time needed to internalize group norms and to form bonds of affection.

A number of factors can lead to dense networks and long-term relationships, including a dense network of community groups, norms of cooperation, long tenure of oneself and one's neighbors in the community, ethnic and linguistic homogeneity and close ties to extended family.

\section{The Social Capital}

In generic terms, the term capital refers to the set of available resources, by individuals as well as social communities in order to accomplish their future necessities with gratification. Moreover, in reference to the actual term defined by the Social Resource Theory (Social Resource Theory, Lin, 1982, 1990, 2001), they usually refer social capital to the group of information, services, goods, affections, and all sort of general resources, which all individual or collective have access, as a consequence of their membership to certain social networks.

Along with the human capital theory, concept labored basically labored during the sixties by Schultz (1961) and Becker (1964), and two decades later the notion of cultural capital (Bourdieu, 1980, 1985), the term social capital after many definitions and modifications, has turned out to be part of what is called the new capital theories (the neo-capital theories), in relation with the Marxist classic theory (Lin, 1999). The social capital has to do with the creation, access and efficiency of the resources within the network and social structures (Lin, Cook, \& Burt, 2001).

Its origins go back to classic authors such as Adam Smith and Montesquieu (Sturgess, 1997; Woolcock 1998; Schuller et al., 2000). For the majority of writers, it is defined in terms of networks, norms and trust, and the way these allow agents and 
institutions to be more effective in achieving common objectives.

The fundamental commence explained by the document carried out by the social capital in the development of a community is the set of resources generated in the social networksconfidence, reciprocity, information and cooperation, that creates value for the people who are linked to the network (Putman, 2000). Baron, Field y Schuller (2000) show their interest on this point of view by the distance moved of the analysis center of conduct from the individual agents to the patterns of relations between agents, social unities and institutions. Also Kawachi et al. (1997) or Lomas (1998) have manifested the influence that the social capital has, as one of the most important facts of the health levels in a community.

Never the less, we find ourselves with one reality in our society: abortion seems to frustrate the expectations put at risk by the social capital. The reason is quite simple: the rupture brought by abortion in comparison to the confidence, reciprocity and cooperation. Let's briefly focus on some important data given in the $\mathrm{EU}$.

\section{Some Important Data}

In Europe (EU-27 and the rest of Europe) 2.9 million abortions (2,863,649 abortions) were carried out in 2008 of which more than one million two hundred thousand $(1,207,646)$ abortions were carried out in the EU-27, per year (Figure 1).

This means that in the EU-27 there is an abortion every 26 seconds; 138 abortions per hour; and 3309 abortions per day.

In fact, in 2008, three out of every four abortions (77\%), were carried out in the countries of the EU-15-for the developed countries - with a total sum of nearly 1 million abortions per year; while the countries of the extended European Union there were fewer than 300,000 abortions per year.

This information verifies that in the last 15 years 20 million children $(20,635,919)$ have been lost via abortion in EU-27. Two out of every three abortions (63\%) was carried out in EU-15, and 7,586,844 (37\% of the total) in the countries of the extended European Union (Figure 2).

Romania, France and United Kingdom are, with a difference, the countries of the UE-27 with the largest number of abortions in the period 1994-2008. Although the number in the abortions in Romania has descended, going from 530,191 abortions in 1994 to 127,907 in 2008 (Figure 3).

The number of abortions per year in Europe (2.9 million abortion) in 2008 is equivalent to the population of Estonia (1.3 million people), Cyprus (0.8 million people), Luxembourg (0.5 million people), and Malta ( 0.4 million people) together; or the entire populations of Slovenia (2 million people), Latvia (2.2
2008

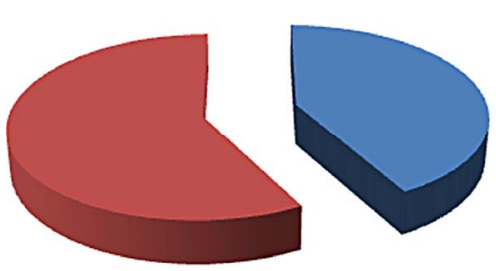

$\square$ Abortions in the rest of Europe not EU 27 (1.656.003$58 \%)$
Figure 1.

Abortions in EU 2008.
The Sum of Abortions (1994-2008)-Eurosat

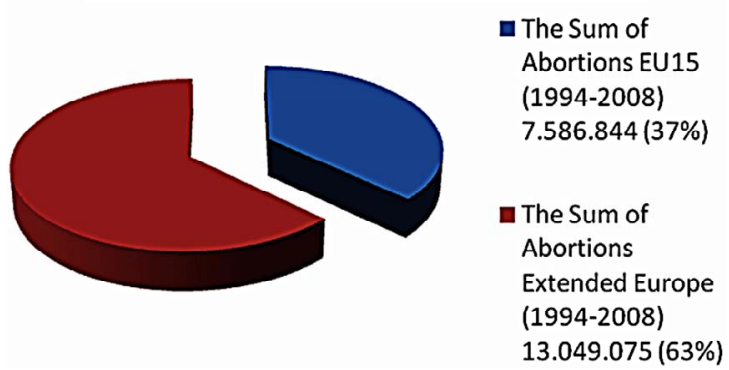

Figure 2.

The sum of abortion (1994-2008).

- The Sum of Abortions (1994-2008) by countries

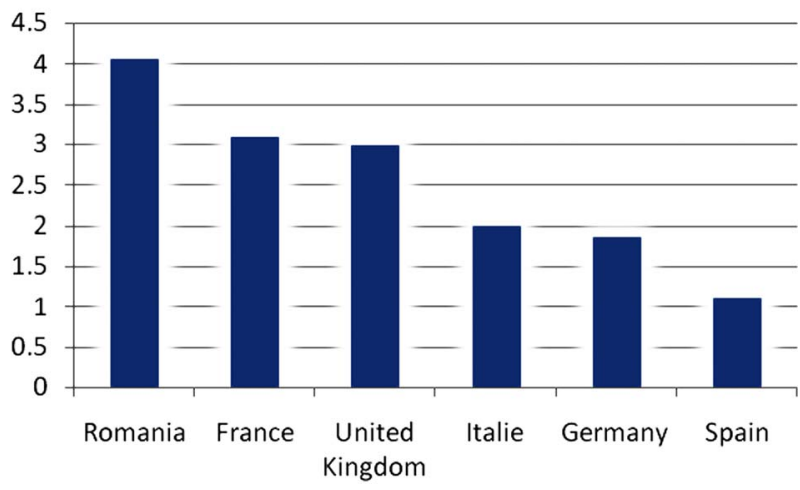

Figure 3.

The sum of abortions (1994-2008) by countries.

million people) or Lithuania (3.3 million people).

Likewise the number of abortions in EU-27 in 2008 (1.2 million abortions) is the equivalent of the populations of Luxembourg and Malta together.

Each year due to abortion the equivalent of the populations $f$ Luxembourg and Malta are lost, or the entire populations of Slovenia or Cyprus.

These data express that abortion is the prime cause of mortality in Europe (Figure 4).

To conclude, abortion is causing verified effects in the population of the EU-27 and that have directly affected the perspective provided to us by the Social Capital against the Human Capital and its logic ruined.

Therefore, we can summarize to point out with the information mentioned that:

- The number of abortions in EU-27 in one year $(1,207,640)$ is equivalent to the deficit in the birth rate in Europe.

- Daily, 3309 children are not born due to abortion in EU-27. This is the equivalent of 2 middle size schools vanishing every day for lack of children.

- In 12 days in EU-27 there are more abortions than deaths on the road in an entire year (39,000 dead in 2008).

- In the last 15 years (1994-2008) the number of abortions adds up to 20 million. This represents the populations of Romania and Netherlands. Although the number of abortions in Romania has descended, going from 530,191 abortions in 1994 to 127,907 in 2008. 


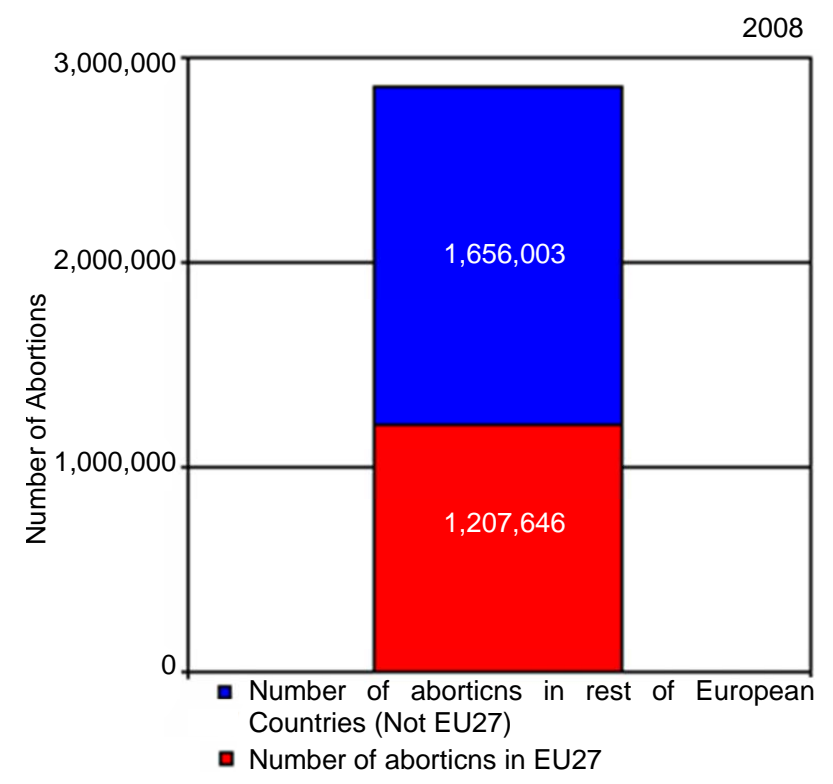

Source: institute for Family Policeies (IPF) drawn from and National data.

Figure 4.

Number of abortion in EU.

\section{Trust and Cooperation as Social Bond}

It has been previously mentioned that the premise underlying social capital is that interaction enables people to create communities, to form commitments and weave social networks. There is no doubt that these facts undermine the interaction that underlines in the social capital and with it the confidence and cooperation that within them.

This interaction means that one of the main components of social capital is the trust between individuals and social institutions. John Locke said many years ago that trust is vinculum societatis, "the bond of society" (1954: p. 213). Many other scholars have expressed this in similar terms. Blau (1964: p. 99) points out that trust is "essential for stable relationships". Trust is necessary for solving problems in an effective way and even for the survival of communities: "when trust is destroyed, societies falter and collapse”, affirms Bok (1979: p. 26). Y esa flaqueza se manifiesta socialmente, entre otros muchos factores, en el aborto.

Alongside trust, we find cooperation. Social capital is related to capacity for cooperation. In this sense, Francis Fukuyama (1995: p. 10) understands social capital as "the ability of people to work together for common purposes in groups or organizations". Trust is so important for cooperation in any organization or society that Zucker (1986: p. 56) does not hesitate to state that it is "vital for the maintenance of cooperation in society and necessary as grounds for even the most routine, everyday actions."

Trust and cooperation require each other, because of the need that everyone has to belong and to be bonded to others. This in turn means that frequent interaction and concern for each other's well-being are necessary. It is essential for people to feel connected in affective terms to other people, and this is not only a question of knowing people or maintaining social contacts, but also of needing deeper relationships such as those which exist within the family. "What makes the family different from a mere aggregate of human beings joined for reasons of subsistence is revealed by the fact that other goals are sought in that bonding. We become united so that each one can live-so that each has a good life or can live well. In fact, those goals do not exclude each other. One refers to subsistence, the other to welfare, and the third includes higher goals, above all love. Love involves a spectrum of human phenomena, arising from intimacy, and it ranges from pleasure in qualities that satisfy us to the gift of self and the acceptance of a person for what he or she is.” (Bernal, 2008: p. 100).

One major aspect of what has been said about social capital is precisely its relational nature, which is directly connected to the moral density of which Durkheim wrote, for which it is necessary to have both material density and volume. From this perspective, sociology stresses the necessity and usefulness of robust structures which make society strong. It is symptomatic that anomie, one of the pathologies mentioned by Durkheim, should be precisely the element which social capital prevents, through a large number of remedies suggested by the authors cited above, all of which revolve around a single point, which is that society is reinforced if its structures are endowed with social capital. The data referring abortion reflect a certain type of anomie, that is, the EU selfish anomie mentioned by Durkheim, which must be given a response.

\section{The Principle of General Reciprocity}

There is no doubt that one of these structures that strengthen society is the family. If it was enough until now to state that the family is the basic unit of society, in order to comprehend its unique depth and importance, we can now make a similar assertion, which is that the family is the place where social capital is formed (Crosnoe, 2004) and is the main source of social capital for young people, especially in relation to their education (Furstenberg \& Hughes, 1993; Hetherington, 1998). In other words, "the social capital which is present in the relations between parents and children should be associated with the internalization of social behavior in the young" (Parcel \& Menaghan, 1993: p. 120). If marriage is the main producer of social capital through the birth and rearing of children, family relations are the secondary network which multiply and secure the human and physical capital which a society needs to develop and progress.

Crosnoe (2004: p. 268) is more explicit about the way in which the family creates social capital. "As children move through the education system, parents can provide instrumental assistance, spread information about education and future opportunities, establish and reinforce the rules of behavior expected, and offer support as children navigate new scenarios, conveying their own experiences of both success and failure." It's within the family like no other place, where the fundamental components of social capital are found: confidence and cooperation. With this said, and as it has been shown by the indicators we pointed out, abortion does not precisely contribute to the idea of family being creator of social capital.

The confidence and the cooperation of a third element is the key to comprehend the social capital: the principle of general reciprocity. As Taylor shows (1982: pp. 28-29), “in a system of reciprocity, each individual act is usually characterized by a combination of what we call altruism in the short term, and self-interest in the long term: I will help you in the hope (possi- 
bly vague, uncertain and not premeditated) that you will help me in the future. Reciprocity is made up of a series of acts, each of which is altruistic in the short term (benefiting others at the cost of the altruist), but which as a whole tend to improve the condition of all the interested parties". Who does not benefit from the reciprocity in the fetus that has been excluded from that relationship. But on another hand it can also be said by the civil society. That's how The Witherspoon Institute (2006: p. 12) points it out to be "civil society also benefits from a stable civil order. Families are small societies, and the network of trust established across generations and between spouses within the family is a key factor for society as a whole. The network of family members and the laws that create and sustain marriage are a key element in the 'social capital' which facilitates the creation of many kinds of civic association and private groups. The virtues acquired within the family, such as generosity, sacrifice, trust, self-discipline, are crucial in all areas of social life. Children who grow up in broken homes often fail to acquire these basic habits of character. When broken marriages are frequent or there is an unstable situation regarding marriage in general, society is damaged by a series of social pathologies, including a rise in poverty, mental illness, delinquency, illegal use of drugs, clinical depression and suicide”.

What can we do to create social capital? According to Coleman, three factors can have a positive impact on its creation: first, the degree of closeness in the relations between different kinds of actors in one organization; second, stability is a critical factor; and last, so is the sense of identity between members. Instead of hierarchical power, "relational power" is required, that is, the capacity to get people to do things collectively through relations of trust and cooperation. The family can thus be " $a$ source of social capital by expansion: expanding family trust to relations that are not properly speaking family relations; or, in other words, it can create within society the environment needed for trust to grow and flourish, and the seeds of this trust are precisely those values that are transmitted within the family" (Llano, 2002: p. 179).

\section{Conclusion}

As it has been carried out in this paper, three are the fundamental elements for the social capital's development: confidence, cooperation and the general principal of reciprocity. These three principals are found within the family as a social capital source, whose benefits are not only the members but the whole civil society itself. The abortion data provided by the EU-27 verifies that the pillars in which the European civil society relies on are being undermined. The existence of social pathologies or anomie, as Durkheim recalls, do not help or benefit the family and society's civil development.

According to what has been mentioned, we apply that there are factors that induce to believe that the social capital in the EU-27 is in decline. Is there hope for any suggestion? Faced with the situation described and aiming to strengthen the social capital in the EU-27, it would seem appropriate amongst other issues, to encourage some standards of behavior that are lacking now a day. Furthermore, we should point out:

- The promotion of public policies that guarantee the rights of the unborn child and the rights of women to maternity; as well as to set up support systems for pregnant women.

- To increase public resources from administrations, including budgeting.

- Finally, to launch campaigns to re-evaluate, rethink, the importance both personal and social, of maternity, pregnancy, birth.

\section{Acknowledgements}

The authors would like to thank special editor and the blind reviewers of previous drafts of this article for their valuable comments and suggestions. We also acknowledge the valuable contribution of Ines Reig for the conclusion of this paper.

\section{REFERENCES}

Baron, S., Field, J., \& y Schuller, T. (2000). Social capital: Critical perspectives. Oxford: Oxford University Press.

Becker, G. (1964). Human capital. New York: Columbia University Press.

Bernal, A. (2008). Educational framework of personal relationships. In A. Bernal, F. Altarejos, \& A. Rodriguez (Eds.), Family as primary educator. A sociological study. New York: Scepter Publishers, Inc.

Blau, P. M. (1964). Exchange and power in social life. New York: Wiley.

Bok, S. (1979). Lying: Moral choice in public and privaten life. New York: Vintage Books.

Bourdieu, P. (1980). Le capital social: Notes provisoires. Actes de la Recherche en Siences Sociales, 31, 2-3.

Bourdieu, P. (1985). The forms of capital. In J. G. Richardson (Ed.), Handbook of theory and research for the sociology of education (pp. 241-258). Nueva York: Greenwood Press.

Borgatti, S. P., Jones, C., \& Everett, M. G. (1998). Network measures of social capital. Connections, 21, 27-36.

Coleman, J. (1988). Social capital in the creation of human capital. American Journal of Sociology, 94, S95-S120.

Crosnoe, R. (2004). Social capital and the interplay of families and schools. Journal of Marriage and Family, 66, 267-280. doi:10.1111/j.1741-3737.2004.00019.x

Fukuyama, F. (1995). Trust: The social virtues and the creation of prosperity. New York: Free Press.

Fudenberg, D., \& Maskin, E. (1986). The folk theorem in repeated games with discounting or with incomplete information. Econometrica, 54, 533-556. doi:10.2307/1911307

Furstenberg, F., \& Hughes, M. E. (1993). Social capital and successful development among at-risk youth. Journal of Marriage and the Family, 57, 580-592. doi:10.2307/353914

Grootaert, C., \& van Bastelaer, T. (2002). The role of social capital in development. Cambridge: Cambridge University Press. doi:10.1017/CBO9780511492600

Hechter, M. (1987). Principles of group solidarity. Berkeley: CA University of California Press.

Hetherington, E. M. (1998). Social capital and the development of youth from nondivorced, divorced and remarried families. In W. A. Collins, \& B. Laursen (Eds.), Relationships as developmental contexts (pp. 177-209). Mahwah, NJ: Erlbaum.

Kawachi, I., Kennedy, B. P., Lochner, K., \& y Polthrow-Stith, D. (1997). Social capital, income inequality and mortality. American Journal of Public Health, 87, 1491-1498. doi:10.2105/AJPH.87.9.1491

Knack, S., \& Keefer, P. (1997). Does social capital have an economic payoff? Quarterly Journal of Economic, 112, 1251-1288. doi:10.1162/003355300555475

Llano, C. (2002). Falacias y ámbitos de la creatividad: El acto de creación en la empresa. México: Limusa.

Locke, J. (1954). Essays on the laws of nature. Oxford: Clarendon Press.

Lin, N. (1982). Social resources and instrumental action. In P. V. Marsden, \& N. Lin (Eds.), Social structure and network analysis (pp. 131-145). Beverly Hills, CA: Sage.

Lin, N. (1990). Social resources and social mobility: A structural theory of status attainment. In R. L. Breiger (Ed.), Social mobility and social structure (pp. 247-271). Nueva York: Cambridge University 


\section{A. RODRÍGUEZ-SEDANO ET AL}

Press.

Lin, N. (1999). Building a network theory of social capital. Connections, 22, 28-51.

Lin, N., Cook, K., \& Burt, R. S. (2001). Social capital. Theory and research. Nueva York: Aldine de Gruyter.

Lin, N. (2001). Social capital. A theory of social structure and action. Cambridge: Cambridge University Press. doi:10.1017/CBO9780511815447

Lomas, J. (1998). Social capital and health: Implications for public health and epidemiology. Social Science and Medicine, 47, 11811188. doi:10.1016/S0277-9536(98)00190-7

Parcel, T. L., \& Menaghan, E. G. (1993). Family social capital and children's behavior problems. Social Psychology Quaterly, 56, 120135. doi:10.2307/2787001

Putnam, R. (1995). Bowling alone: America's declining social capital. Journal of Democracy, 6, 65-78. doi:10.1353/jod.1995.0002

Putnam, R. (1996). The strange disappearance of civic America. The American Prospect, 24, 34-48.

Putnam, R. (2000). Bowling alone: The collapse and revival of American community. New York: Simon \& Schuster.

Schuller, T., Baron, S., \& Field, J. (2000). Social capital: A review and critique. In Baron et al. (Eds.) Social capital: Critical perspectives. Oxford: Oxford University Press.

Schultz, T. W. (1961). Investment in human capital. The American Economic Review, 51, 1-17.

Sturgess, G. (1997). Taking social capital seriously. In A. Norton, M.
Latham, G. Sturgess, \& M. Stewart-Weekes (Eds). Social capital: The individual, civil society and the state. St. Leonards, NSW: Centre for Independent Studies.

Taylor, M. (1982). Community, anarchy and liberty. Nueva York: Cambridge University Press. doi:10.1017/CBO9780511607875

The Witherspoon Institute (2006). Marriage and the public good: Ten principles. Princenton: New Jersey.

Thomas, J. P., \& Worrall. T. (2002). Gift-giving, quasi-credit and reciprocity. Rationality and Society, 14, 307-351. doi:10.1177/1043463102014003003

Torsvik, G. (1999). Social capital and economic development: Searching for explanations. Bergen: University of Bergen.

Torsvik, G. (2000). Social capital and economic development: A plea for the mechanisms. Rationality and Society, 12, 451-476. doi:10.1177/104346300012004005

Woolcock, M. (1998). Social capital and economic development: Toward a theoretical synthesis and policy framework. Theory and Society, 27, 151-208. doi:10.1023/A:1006884930135

Woolcock, M., \& y Narayan, D. (2000). Social capital: Implications for development theory, research, and policy. The World Bank Research Observer, 15, 225-249. doi:10.1093/wbro/15.2.225

Zucker, L. G. (1986). Production of trust: Institutional sources of economic structure, 1840-1920. In B. M. Straw, \& L. L. Cumming (Eds.), Research in Organizational Behavior (pp. 53-111). Greenwich, CT: JAI Press. 